Jusmal llmial

PFUR AT DE

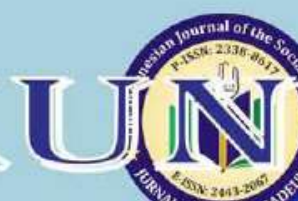

Vol. 5, No. 3, September 2017

$\int_{\substack{\text { Indrjesident } \\ \text { si in }}} 1$

sCAD Intependent Acreditatiou by 100 since 2014 $\bigodot$ Copernicus Publications

\section{JIP}

The Indonesian Journal of the Social Sciences www.journal.scadindependent.ors D01 Prefix Number; 10,26811
Csinta

INDEX COPERNICUS 


\title{
THE RELATIONSHIP OF MOTIVATION AND JOB SATISFACTION OF SCHOOL PRINCIPAL AT THE STATE JUNIOR HIGH SCHOOL IN KARAWANG REGENCY
}

\author{
Herlina1; Linda Ika Mayasari'; Sukma Desi ${ }^{3}$ \\ 1,2Sekolah Tinggi Keguruan dan Ilmu Pendidikan Kusuma Negara Jakarta, Indonesia \\ ${ }^{3}$ State Junior High School 2 Cilamaya Kulon, Karawang, Indonesia \\ 1Contributor Email: herlina.mahtum@stkipkusumanegara.ac.id
}

Received: April 10, $2017 \quad$ Accepted: Sep 12, $2017 \quad$ Published: Sep 28, 2017 Article Url: http://journal.scadindependent.org/index.php/jipeuradeun/article/view/139

\begin{abstract}
The objective of this research was to determine the Relationship between Motivation and Job Satisfaction of Principal at The State Junior School in Karawang. In doing the research, it has been conducted by using quantitative approach with the method of survey and corelational technique. The data were collected through participant observation using survey by questionnaires. The data analysis using simple correlation and simple linear regression. The target population size of this research is 85 of Principal. Research samples selected as many as 57 principals using simple random sampling technique. Based on this research of data obtained the following conclusions: The motivation has positive relationship to job satisfaction, the job satisfaction can be improved by increasing the motivation.
\end{abstract}

Keywords: Motivation, Job Satisfaction, the State Junior High School, Karawang 


\section{A. Introduction}

Education is a process of building next-generation with the great quality results, wherever they are involved with. Along with this, of course so many factors are taking part here. Besides, the education will succeed if they are running it well with a clear goal to achieve, so, the best graduates are coming then. Therefore, it is needed such a professional also creative to keep the vision, mission, as well as the goal of education in running this field. The ones who manage the regulations of primary and secondary are school principals. With their competencies, both school principal and his professional education workers as the human resource of the field are able to fulfill their jobs and responsibilities in keeping the lesson to run well. It is the ability and policy of the principal, determine if an education program works, or even more if the education goal is achieved or not.

Job satisfaction is kind of pleasant feeling that specifically here is felt by the school principal regarding to his job. By the time the principal is fulfilled by his social need and self-actualization, he gets motivated to do his job. However, when he only gets his satisfaction limitedly from his job instead of his social need and self-actualization, then he won't get motivated in doing the job yet he only reduces his dissatisfaction state. For instance, a school principal with his expected salary on the hand, definitely get satisfied by it, but still, it isn't a guarantee for him to get motivated to do his jobs and take all of his job responsibilities. Again, if the principal is fulfilled by his self-actualization, there he naturally gets motivated doing his job since people that is highly motivated are those who get their selves with self-actualization.

For a school principal, to be motivated to develop the quality of education that he runs with the job satisfaction, or rather than with creativity is kind of two sides of a coin. In fact that job satisfaction of school principal can develop his job motivation, then motivation are developing the creativity at the same time.

Based on the explanation above, it can be stated that some factors are correlated to the job satisfaction. Then regarding to it, the researchers are desired to do a research of, "The Relationship of Motivation and Job Satisfaction of School 
Herlina et al.

Principal at The State Junior School in Karawang Regency". The researchers are attracted in taking those variable because the satisfaction of the principal of The State Junior School is really determined the goals of school that also makes the goals of education as in general are achieved.

\section{B. Method}

In doing the research, it has been conducted by using quantitative approach with the method of survey and correlational technique. It is The State Junior School in Karawang Regency is chosen to do the research. While the number of research population is 85 principals of all chosen The State Junior School in Karawang Regency, the number of sample that has been taken is 57 principals. Furthermore, in order to analyze the available data of the research, it is required to do a test of hypothesis which has been formed using both models of simple linear regression analysis and multiple linear regression analysis.

Those linear regression models are used to interpret the relationship of the two variable of the research. Technically, before the simple linear regression analysis, the significance regression test and the linear regression test as the statistical requirement are applied, the normality test of each research variable is conducted using Liliefors-test.

\section{Research Finding}

As the hypothesis tested, it can be concluded that there is positive relationship between motivation and job satisfaction. The hypothesis test of the research is formulated into such statistical hypothesis below:

$$
\begin{aligned}
\mathrm{H}_{0} \quad: \rho_{\mathrm{y} 1} \leq 0 \\
\\
\quad \text { There isn't any correlation between motivation and job } \\
\text { satisfaction. } \\
\mathrm{H}_{\mathrm{i}} \quad: \rho_{\mathrm{y} 1}>0
\end{aligned}
$$

There is correlation between motivation and job satisfaction.

By calculating as in simple regression analysis and based on the score of motivation and job satisfaction variable, it is dragged onto the regression of $b$ equals 0,722 and constant of a equals 34,409. The 
relationship between the two variable are formulated as in $\hat{Y}=34,409+$ $0,722 \mathrm{X}_{1}$. Before the formulation is used to predict the result of research, the regression has to fulfill both criteria of significance test and linearity test. In getting to know the significance degree also its linear regression, it is needed to do such F-test as in the table below:

Table of ANAVA (Significance test and Linear Regression)

$$
\hat{Y}=34,409+0,722 X_{1}
$$

\begin{tabular}{|l|c|c|c|c|c|c|}
\hline \multirow{2}{*}{$\begin{array}{c}\text { Variance } \\
\text { Source }\end{array}$} & Dk & JK & \multirow{2}{*}{ RJK } & $\mathbf{F}_{\text {count }}$ & \multicolumn{2}{|c|}{$\mathbf{F}_{\text {table }}$} \\
\cline { 6 - 8 } & & & & & $\mathbf{a}=\mathbf{0 , 0 5}$ & $\mathbf{a}=\mathbf{0 , 0 1}$ \\
\hline Total & 57 & 775320 & - & & & \\
\hline Coefficient a & 1 & 773967,789 & 773967,789 & & & \\
Regression (b/a) & 1 & 722,905 & 722,905 & $63,180^{* *}$ & 4,016 & 7,119 \\
Residue & 55 & 629,306 & 11,442 & & & \\
\hline Tuna Cocok & 16 & 219,389 & 13,712 & $1,305^{\mathrm{ns}}$ & 1,911 & \\
Errors & 39 & 409,917 & 10,511 & & & \\
\hline
\end{tabular}

Explanation:

$\left.{ }^{* *}\right) \quad$ : Highly Significance Regression $\left(\mathrm{F}_{\text {count }}=63,180>\mathrm{F}_{\text {table }}=\right.$ $7,119)$

with $a=0,01$

ns) : Linear Regression $\left(\mathrm{F}_{\text {count }}=1,305<\mathrm{F}_{\text {table }}=1,911\right)$ with $\alpha=0,05$

dk : Degrees of freedom

JK : Sum of Squares

RJK : Average Sum of Squares

Based on the table of ANAVA, the significance of regression is proved, thus it is gotten that $F_{\text {count }}(63,180)>F_{\text {table }}(7,119)$ towards $\alpha=0,01$. This is literally shown that the regression model here is highly significant. Besides, by the linearity test, it's been found that $F_{\text {count }}(1,305)<F_{\text {table }}$ $(1,911)$ towards $\alpha=0,05$. This means the hypothesis proposed as in linear regression is accepted, the equation is just linear. After conducting such a calibration of testing process, it's decided that the linear regression model 


\section{Herlina et al.}

of $\hat{Y}=34,409+0,722 X_{1}$ is required to interpret the relationship between motivation and job satisfaction. It is clearly shown the tendency of job satisfaction is followed after motivation as in picture 4.4 below:

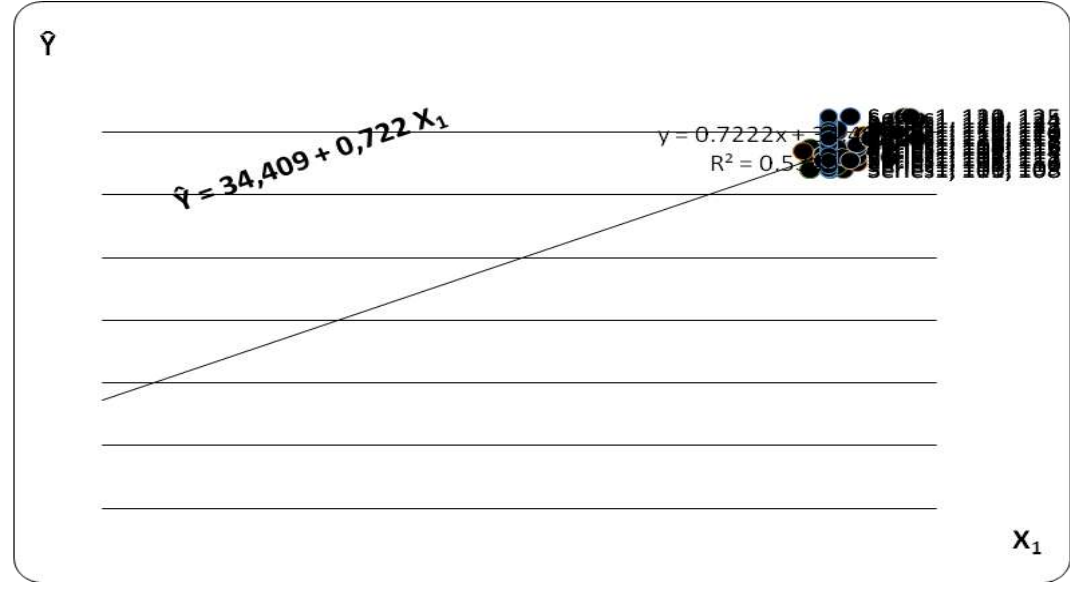

Graphic of Relationship between Motivation and Job Satisfaction Based on the equation $\hat{Y}=34,409+0,722 X_{1}$

The equation of linear regression $\hat{Y}=34,409+0,722 X_{1}$ provides an acceptable approximation to the true relationship between motivation and job satisfaction that is measured using the instruments of the research. It makes every 1 score that increased is followed by the increasing of another score of job satisfaction as 0,722 towards the amount of constant 34,409 . The strength of relationship between both variables of motivation and job satisfaction is proved through coefficient $\left(\mathrm{r}_{\mathrm{y} 1}\right)$ as in 0,731 . After all, t-test is required to test the significance of correlation coefficient that brings $t_{\text {table }}=1,673$ with $\alpha=0,05$ and $t_{\text {table }}=2,396$ with $\alpha=0,01$ while for $t_{\text {count }}=7,949$. Due to the reason of $t_{\text {count }}>t_{\text {table, }}$ it is drawn that correlation coefficient $\left(r_{y 1}\right)$ is definitely significant. It can be seen as in the table 4.6 below:

Table of Significance Correlation test $X_{1}$ and $Y$

\begin{tabular}{|c|c|c|c|c|}
\hline \multirow{2}{*}{$n$} & $\begin{array}{c}\text { Coefficient } \\
r_{y 1}\end{array}$ & $t_{\text {count }}$ & \multicolumn{2}{|c|}{$t_{\text {table }}$} \\
\cline { 4 - 5 } & & & $\alpha=0,05$ & $\alpha=0,01$ \\
\hline 57 & 0,731 & $7,949^{* *}$ & 1,673 & 2,396 \\
\hline
\end{tabular}




\section{Explanation:}

** : Significant Correlation Coefficient $\left(\mathrm{t}_{\mathrm{count}}=7,949>\mathrm{t}_{\mathrm{table}}=\right.$ 2,396) towards $\alpha=0,01$

$r_{\mathrm{y} 1}$ : Correlation Coefficient between $\mathrm{X}_{1}$ and $\mathrm{Y}$

$\left(r_{y 1}\right)^{2}$ : Determination Coefficient between $X_{1}$ and $Y$

Based on the significance test above, the correlation coefficient between motivation and job satisfaction is highly significant. Therefore, the research hypothesis that there is positive correlation between motivation and job satisfaction is practically accepted. It means, the better motivation state of school principals, the higher satisfaction level is gained.

Determination coefficient is squares of correlation between motivation and job satisfaction. Its computation presents $\left(\mathrm{r}_{\mathrm{y} 1}\right)^{2}=(0,731)^{2}=$ 0,535 . All things considered, that $53,50 \%$ of variance for job satisfaction is defined along with variance of motivation.

\section{Discussion}

Mc Shane (2008:115), “job satisfaction is a person's evaluation of his or her job and work context. Satisfied employees have favorable evaluation of their job based on their observation and emotional experiences".

Laurie J. Mullins (2010:282) has stated that, "job satisfaction is a complex and multifaceted concept, which can mean different thing to different people. It is usually linked with motivation, but nature of this relationship is not clear. Satisfaction is not the same as motivation. Job satisfaction is more of an attitude, an internal state. It could, for example, be associated with a personal feeling of achievement, either quantitative or qualitative". Referring to what has been stated above, it is job satisfaction commonly assumed to be a needed of being highly motivated in doing a job. On the contrary, despite level of job satisfaction might affect the state of motivation, but this is not always experienced.

Steven L Mc Shane (2008: 115) defined, “job satisfaction, a person's evaluation of this or her job and work context, is probably the most studied attitude in organizational behavior. It is an appraisal of the perceived job characteristic, work environment, and emotional experiences at work. 
Satisfied employees have a favorable evaluation of their jobs, based on their observation and emotional experiences. Job satisfaction is really a collection of attitudes about different about different aspect of the job and work context". Job satisfaction is determined based on a person's evaluation towards a job that he is in charge, then it makes a state of satisfaction for each person is different in terms of how an individual evaluates characteristics of the job that he is doing, the job's environment that he is surrounded, as well as his expectations of the job itself. When someone has been doing a big opportunity of his job with a finest state and get paid off as he expects, then he gets satisfied right after. On the other hand, if it doesn't reach his expectation, thus dissatisfaction is coming as a result.

Meanwhile, as it has been quoted from Fred Luthans, Locke (2008:141) has also stated that, "job satisfaction is a pleasure or positive emotional state resulting from the appraisals of one's job or job experience. Fred Luthans gives a comprehensive definition of job satisfaction is a result of employees' perception of how well their job provides those things that are viewed as important".

In other statement, Luthans (2002: 230-231) also explained, "Job satisfaction represents several related attitudes. Through the years five job dimensions have been identified to represent the most important characteristic of job about which employees have been affective responses. These are: a) The work itself, b) Pay, c) Promotion Opportunities, d) Supervision, e) Coworkers". As it has been stated about five job dimensions, the first, it's the work itself. In this term, work gives us exciting stuffs to do, a chance to learn, and even more it gives us a chance to take all responsibilities that it remains. Then the second dimension is terms of salary. The amount of salary is measured based on how much workload is given.

Next dimension is promotion opportunities that means great progress in this career. Another dimension that also affects job satisfaction is supervision. As for the last, among coworkers that is living the harmony and always recommending a better for each other, will also give the most point in building job satisfaction. Talking about satisfaction, it can't go far from how someone defines and reach it. 
In fact, people can do some ways to get the satisfaction in his job, and that is because of each person has their own self-character. However, the things that needs to be considered is the way someone gets satisfied in his job because once someone get satisfied then he feels be honored, hence he is willingly doing his job. Every individual has their own state of satisfaction as in the valuable system that runs in their selves. The better someone reach his expectation while doing his work, the more he gets satisfied towards it.

Stepen P. Robbins (1986:104) stated about job satisfaction as, "Job satisfaction refers to an individual's general attitude toward his or her job". People with such a well satisfaction towards their jobs, has the positive side of attitude in doing the jobs, they feel happy about the jobs. Unlike those with the negative side of attitude to the jobs, these people will not feel happy about their jobs. In that case, it will decrease both of their job motivation and job responsibilities.

As the explanations above, it can be synthesized that job satisfaction is the feeling of someone's pleasant and unpleasant related to the jobs with their response towards some indicators that are job itself, income or salary, promotion opportunities, supervision, and their coworkers.

As in Richard L. Draft (2010: 506) says, "Motivation the arousal, direction, and persistence of behavior". There are two kinds of motivation, intrinsic and extrinsic motivation. Intrinsic motivation is a satisfaction state that is gotten in the process of doing things, while extrinsic motivation is a gift from other people.

R. Wayne Monday (1991: 312), "motivation is the desire to put forth effort in pursuit of organizational goals". Besides Luthans (2005: 269), "Motivation is a process that starts with a physiological or psychological deficiency that drives behavior or intended for the purpose of encouragement or intensive". Therefore, the key of understanding process of motivation is depending on how we define and cooperate the needs, support, and incentives together. The need drives people to support for an incentive goal, and that's how motivation works, which in a system, it involves three elements that are needs, support, and incentives. 


\section{Herlina et al.}

Laurie J, Mullins (2010: 253), "motivation is the creation of stimuli, incentives, and working environments that enable people to perform to the best of their ability. The heart of motivation is to give people what they really want most from work. In return managers should expect more in the form of productivity, quality, and service".

Based on the statements above, it can be synthesized that motivation is someone's behavioral support, desire and needs that drives him into putting his all efforts through activity and his works for getting what he expects, with some indicators, they are a desire to succeed, an effort to take all responsibilities in his job, expecting to be given suggestions, getting used to face all challenges, and being oriented to the goals.

As the result, by analyzing the correlation between motivation and job satisfaction, it has been gotten that the amount of correlation coefficient is 0,731 with its $t_{\text {count }}=7,949$ at its $a=0,01$. By then, the relationship between motivation and job satisfaction are pointed to a highly positive correlation. That means, the higher motivation, the better satisfaction of school principal is expected.

Related to the theory of the relationship between motivation and job satisfaction as in Mullins (2010: 282) stated, "Motivation and job satisfaction are very subjective and affected by many variables including cultural influences, unknown domestic situations and personal relationships outside of work". Motivation and satisfaction are kind of two sides of a coin. In fact that job satisfaction can develop someone's job motivation.

As the explanation above, it could be drawn that motivation and job satisfaction are positively correlated. As in the higher motivation, the better state of satisfaction is gained.

\section{E. Conclusion}

After all research analysis, it can be concluded that "There is positive relationship between motivation and job satisfaction of school principals at The State Junior School in Karawang Regency. The better motivation state of school principals, the higher satisfaction level they gained. 


\section{Bibliography}

Achariya, Issarapaibool. (2008). Effect of image creativity and service quality on customer satisfaction and firm performance: an empirical investigation of service business firms. International Journal of Business Strategi, Volume: 8 Issue, 1, Jan.

Daft, Richard L. (2010). New Era Management Ninth Edition. Canada: Vanderbilt University.

Grifiin, Ricky W. (2004). Manajemen Jilid 2, Edisi Ketujuh. Jakarta: Erlangga.

Luthan, F. (2008). Organizational Behavior. New York: Mc Graw Hill.

Lvina, E. (2015). The Role of Cross-Cultural Communication Competence: Effective Transformational Leadership Across Cultures. Jurnal Ilmiah Peuradeun, 3(1), 1-18.

Monday, R. W. (1991). Management Concepts, Practices, and Skills. Boston: Allyn and Bacon.

Mullins, Laurie J. (2010). Management \& Organizational Behavior. Ninth Edition. England: Prentice Hall.

Peter \& Olson. (1996). Perilaku Konsumen dan Strategi Pemasaran, D Sihombing (Penerjemah), Consumen Behavior, Jakarta: Gelora Aksara Pratama.

Robbin, S.P. (1996). Organization Behavior: Concept, Controversies and Application. New Jersey: Prentice-Hall.

Sarboini, S. (2016). Performance of Employees and Impact on Promotion of Position. Jurnal Ilmiah Peuradeun, 4(1), 103-114.

Stepen, R.P. (1987). Organizational Theory. New Jersey: Prentice-Hall International.

Steven, Mc Shane. (2008). Organization Behavior. New York: Mc Graw Hill.

Tyson, S and Jackson, T. (1992). The Essence of Organizational Behavior: Perilaku Organisasi. Yogyakarta: Andi. 